\title{
La lectura compartida d'un àlbum sense text en una aula d'acollida
}

Montserrat Pérez Ventayol, Universitat Autònoma de Barcelona, Espanya

"Las palabras pueden ser una barrera, pero las imágenes visuales son universales”

(Coulthard 2004: 261)

\section{Introducció}

Si algun fet ha caracteritzat les aules del nostre país d'uns anys ençà, el més destacable, probablement, ha estat la incorporació constant d'infants i adolescents vinguts d'arreu del món. La realitat s’ha fet més complexa i diversa, i el sistema educatiu hi ha hagut de respondre amb pràctiques i propostes, sovint innovadores, sovint molt voluntarioses, per poder atendre aquest alumnat, especialment en l'àmbit de l'acollida lingüística inicial.

Si bé en moltes ocasions la diversitat de bagatges lingüístics, culturals i acadèmics s'ha considerat com un obstacle més en el sofert sistema escolar, aquesta diversitat també pot ser entesa com un repte engrescador perquè dóna eines per valorar la realitat que ens envolta amb més coneixement de causa; i perquè estimula la creativitat dels agents implicats en els processos d'ensenyament i aprenentatge.

Donar respostes per a la gestió d'aquesta complexitat lingüística i cultural és un dels objectius de la recerca sobre ensenyament i aprenentatge en entorns plurilingües que des de fa temps s'està portant a terme a les aules del nostre país, i les aules d'acollida ofereixen molt de terreny per poder-hi investigar $i$, en últim terme, per poderhi treballar. Són espais en què és possible promoure la inclusió de propostes i pautes organitzatives i metodològiques innovadores en relació, sobretot, amb l'educació lingüística. I en aquest context, l’educació literària també hi té molt a dir.

L’educació literària, la literatura en general, ja ha mostrat la capacitat que té per desenvolupar d’una manera efectiva i afectiva estratègies per portar a terme propostes d'intervenció educativa cultural i lingüística. En l’àmbit de l'acolliment lingüístic també se li atorga un paper fonamental. Des de la comissió de la Didàctica de la literatura del Consell Assessor de la Llengua a l'Escola (Murgades 2006), es destaca la utilitat de la literatura en la integració de l'alumnat nouvingut, sobretot pel que fa a l'aprenentatge lingüístic, a l'aprenentatge cultural i metaliterari i a l'aprenentatge sobre el coneixement 
del món i de l’altre. L’educació literària és un pont privilegiat a l’hora de portar a terme pràctiques inclusives, participatives i integradores per a tot l'alumnat. En algunes aules d'acollida ja s'ha experimentat aquest potencial, i ja no sobta tant veure nois i noies que, amb molt poc temps entre nosaltres, participen en obres de teatre posant-se en la pell de personatges amb una càrrega cultural tan important com, per exemple, el Manelic de Terra baixa. La literatura ha començat a entrar a les aules d'acollida, si bé sense fer gaire soroll.

Des de fa cert temps, el grup de recerca GRETEL ${ }^{1}$ ha començat a explorar el paper que juga la literatura en contextos plurilingües i pluriculturals. De l'ampli ventall d'interrogants que se’ns genera al voltant d'aquesta qüestió, mostrar de quina manera la literatura pot contribuir a l'aprenentatge lingüístic de l'alumnat nouvingut ens resulta del tot fonamental. De materials per promoure-ho, n’hi ha. D'una banda, trobem els que, de manera adequada a les circumstàncies, acosten la literatura escrita a l'alumnat al·lòcton (poesia, narrativa, teatre...). De l'altra, comptem amb un tipus de text ficcional que conté molts elements efectius per apropar l'alumnat nouvingut a la llengua d'aprenentatge, però que encara és molt poc explotat a casa nostra. Parlem de l'àlbum il·lustrat.

Amb el propòsit de contribuir a plantejar pràctiques innovadores en relació amb l'acolliment lingüístic des de l’àmbit de la didàctica de la literatura, presentem aquest article, l’objectiu del qual és mostrar com la lectura compartida d'un àlbum il-lustrat sense text crea un context afavoridor per a la pràctica de competències de producció oral en català de l'alumnat d'una aula d'acollida.

Les conclusions d'aquest article es fonamenten en els resultats d'una recerca qualitativa $^{2}$ que s'anirà desglossant al llarg d'aquestes pàgines. L'objectiu de la recerca va ser examinar el desenvolupament de la competència lingüística i discursiva oral en català d'un grup d'alumnes d'una aula d'acollida a través de la lectura compartida d'un àlbum sense text. 


\section{Per què els àlbums?}

La introducció dels àlbums a les aules és avui dia poc freqüent, malgrat que presenten unes especificitats que els fan prou vàlids per al treball amb l'alumnat i per a la recerca. Els àlbums ens ofereixen un marc per focalitzar la mirada en les habilitats visuals de l'alumnat, habilitats molt poc explotades a les aules, però de gran importància en un món marcat pel predomini de la imatge; ens donen un punt de partida per a la presa en consideració del bagatge vital que aporta l'alumnat a l'hora de construir significat i de compartir-lo; i ens brinden l'oportunitat de compartir les experiències vitals amb el grup classe que aquests textos narratius fan visibles. Tots aquests aspectes, i d'altres que no hem mencionat, es fan encara més rellevants quan es treballa amb alumnat nouvingut.

Potser un dels motius que ha allunyat els àlbums d'esdevenir un material a tenir en compte per a l'aprenentatge, sobretot a les aules de secundària, és que sovint se'ls ha encasellat dins dels materials que engloben la literatura infantil, i s'han menystingut les seves potencialitats. Però tancar la recepció dels llibres àlbum a aquest grup de destinataris no seria fer justícia als nombrosos autors que han creat i creen materials pensats per a lectors adults. Molts àlbums contemporanis, com moltes novel-les gràfiques o llibres artístics, són concebuts per a un públic adult. Els temes, les línies narratives, els jocs intertextuals s'han eixamplat i s'han fet cada vegada més rics i complexos.

L’àlbum és definit sobretot per la presència destacable, quasi predominant, de la il·lustració i la confluència de dos codis, el lèxic i el visual (Silva-Díaz 2006). Però no sempre s'estableix aquesta relació: podem trobar àlbums sense text. Quan això passa, tota la càrrega narrativa se l'endu la imatge. És quan esdevé un text visual, la lectura del qual reclama certes destreses, però també ofereix molts avantatges, sobretot perquè apareix despullat de qualsevol barrera idiomàtica.

Darrerament, han començat a fer-se públics estudis i recerques entorn la lectura visual. Pel que s’ha pogut constatar, entre d'altres qüestions, és que les característiques de la imatge visual davant les del text escrit permeten que l'alumnat, sigui quina sigui la seva competència lingüística en la llengua d’escolarització, pugui participar més activament en la interpretació del text. Les imatges no estan lligades a cap llengua particular, cosa que permet que siguin interpretades des de qualsevol dels mons lingüístics de l'alumnat nouvingut i aquest és un dels aspectes que fa que el text sigui 
més viu, accessible, personal i que es mantingui la motivació per interpretar el que passa (Datta 2000). La implicació i l'entusiasme que mostren els aprenents els permet superar les barreres idiomàtiques i culturals. La connexió emocional amb el que llegeixen és una de les vies més potents per assumir riscos lingüístics i expressar allò que la imatge els suscita. S’ha demostrat, a més, que a pesar de les distàncies culturals, els àlbums condueixen a activar un ventall de processos cognitius i afectius, sigui quin sigui el nivell de competència de la llengua objecte d'aprenentatge (Arizpe i Styles 2008).

\section{Llegir per parlar?}

Tanmateix, tots aquests processos només són observables si es dóna una condició: que l'alumnat parli del text visual que té entre mans; que verbalitzi tot allò que veu i interpreta. Només així és quan la intervenció de qui fa de mediador pot cobrar sentit i eficàcia: pot saber què sap i què no sap l'aprenent i el pot guiar i ajudar en el seu procés d’adquisició i reelaboració de coneixements d'ordre divers.

L’àlbum ofereix el marc idoni per promoure-ho, ja que com explicita Margallo (2008:6): "Partir de los dibujos para reconstruir la historia parece una estrategia adecuada para fomentar les producciones orales del alumnado al tiempo que se trabajan les competencias narrativas del discurso literario.” I el millor format per treballar-hi l’ofereix la lectura compartida.

De la mateixa manera que fa temps que s'ha demostrat l'eficàcia de dur a terme activitats de lectura compartida del text escrit, la interpretació compartida d'imatges visuals també és un recurs de primer ordre per a la progressiva conformació de “comunitats de lectors”, imprescindibles per a la creació de vincles, tant socials com culturals, entre els membres de la comunitat. Però a més, la lectura compartida té altres aspectes que la converteixen en un tipus de format fonamental per a l'aprenentatge. Crea l'espai idoni perquè es manifesti l'expressió d'allò que el text suggereix a cada lector i l'evocació dels referents que cadascú aporta per interpretar el que té davant. Tot el bagatge d'experiències prèvies literàries s’activa per donar resposta a la informació visual.

La lectura compartida permet observar de quina manera el lector interactua amb el llibre perquè se li ofereix l’oportunitat de verbalitzar tot allò que ocorre en el procés 
de construcció de significat (Silva-Díaz i Manresa 2005). Permet, a més, anar més enllà de la resposta lectora de cada participant; permet que les respostes creixin en la mesura que es van reconstruint i reformulant a través de la interacció amb els altres lectors. I és evident que si s’interactua amb altres lectors es posa a prova, també, la competència comunicativa en llengua meta dels aprenents.

Així, la lectura compartida d’un àlbum proporciona l'espai perquè l'alumnat parli d'allò que narren les il·lustracions, però sobretot perquè comparteixi les interpretacions que fa i les pugui fer créixer amb les aportacions dels altres; en definitiva, proporciona l'espai per comunicar-se.

\section{La recerca}

La recerca que presentem es va dur a terme en una aula d'acollida d'un IES de la ciutat de Rubí (Barcelona), amb set alumnes de primer cicle de l'ESO, d'orígens diversos (Xina, Senegal, Bolívia i Marroc), d'entre un any i any i mig de residència a Catalunya.

El material que ha servit de base per al desplegament de la investigació és l’àlbum sense text El soldadito de plomo ${ }^{3}$, de Jörg Müller (Editorial Lóguez). L'absència de text, les referències al conte original d'Andersen, i la inclusió d'aquest llibre en el corpus de textos que poden facilitar la integració i l'aprenentatge lingüístic i literari de l'alumnat nouvingut (Margallo 2008) van ser els motius principals de la tria. Aquesta obra narra la història d'una joguina, un soldadet de plom, el conegut soldadet de plom d'Andersen, que juntament amb una nina barbie, passen per tot un periple fins a un final en què el destí els ajunta per sempre. Mentre que una primera mirada ens condueix per aquesta línia argumental, una mirada més profunda converteix l'àlbum en una crítica a les desigualtats i a les contrarietats d'un món que es mou entre rics i pobres, entre l'opulència i la misèria.

Es varen dissenyar dos tipus d'activitats de lectura: una entrevista amb la investigadora, que es va fer a l'inici i al final de la seqüència , i una sessió de lectura amb tot el grup de l'aula, entre les dues entrevistes. L'objectiu en tots els casos era que parlessin de l'obra a la vegada que l'exploraven. La comparació de les dades obtingudes en les dues entrevistes havia de proporcionar-nos informació que permetés corroborar l'existència d'una certa millora en la competència lingüística i discursiva de l'aprenent. 
En els dos tipus d'activitats (entrevistes i sessió de grup) predomina un tipus de seqüència d'activitat molt concreta: la que s’orienta cap al sentit i la fluïdesa (Nussbaum 2007). Aquest tipus de seqüència és el més semblant a la comunicació “natural”. Són obertes i imprevisibles en relació amb la participació i als temes que s’hi aborden, i no s’hi sol produir correcció dels errors, ja que el que importa és el sentit i la intercomprensió més que la correcció. D’altra banda, són activitats que es troben a cavall entre l'àmbit conversacional i l’àmbit acadèmic de l'ús de les llengües (Cummins 2000, citat per Nussbaum i Unamuno 2004), ja que hi ha certa demanda cognitiva però a la vegada és una activitat molt contextualitzada, ja sigui per la presència de l'àlbum mentre s'explora, com per la possibilitat de negociar constantment amb la investigadora el significat del que es fa. L'entrevista, a més, com que es configura com una situació comunicativa de caràcter formal, l'alumnat sol respondre-hi orientant el seu comportament cap al que entenen que s'hi reclama; ofereix, per tant, un context interessant per mesurar-ne la competència comunicativa (Nussbaum i Unamuno 2006).

L'entrevista no és una pràctica habitual en una aula d'acollida i menys quan se'ls demana de treballar amb un àlbum il-lustrat, però considerem que és una activitat comunicativa perquè els dos interlocutors esdevenen actors socials en el context en què interactuen. L'entrevista és semidirigida i hi ha la voluntat expressa per part de la investigadora de convertir la pràctica en una explotació conjunta del llibre. La seva actuació s’encamina més a la recerca de la construcció interpretativa i expressiva del llibre que no pas a l'avaluació lingüística dels enunciats emesos. Aquesta actitud respon a la voluntat de ser fidel a les nocions de comunicació i significació a l’hora de portar a terme la pràctica, més que no pas a la concepció que el que s’ha de produir són enunciats correctes.

L'entrada a l'aula d'acollida amb l'àlbum va causar cert impacte als nois i noies. Mai ningú els havia entrat per fer cap recerca, i encara menys amb àlbums i amb la consigna de narrar la història del llibre. Les primeres entrevistes van suposar la primera presa de contacte amb la investigadora, amb la finalitat de l'activitat que duien a terme, amb les expectatives que la investigadora posava sobre ells, amb el repte fer-ho en català, una llengua amb què tot just començaven a familiaritzar-s'hi... massa fronts oberts per a una sola activitat. Però malgrat tot, van acollir l’àlbum entre les seves mans 
i es van llençar a respondre a la seva manera i amb els seus recursos, cadascú des del seu punt de partida, les demandes que investigadora i àlbum els llençaven.

Per a l'anàlisi de les dades es van prioritzar aquells alumnes que haguessin participat en les dues entrevistes de manera individual (de les tres noies marroquines, dues van voler fer l'entrevista inicial conjuntament) i que haguessin assistit a totes les sessions. Dels set alumnes, s'analitzaran les dades de Nadia, Alberto i Thiane, del Marroc, Bolívia i Senegal, respectivament.

\section{Anàlisi de les dades i comentari dels resultats}

Les dades de tipus oral conversacional obtingudes es van transcriure i van ser sotmeses a exploració a partir dels criteris i categories d'anàlisi referenciats en un estudi de Mònica Molina i Lluís Maruny (2004), en què s’analitzava l'adquisició del català per part d'alumnat d'origen marroquí en l'ensenyament secundari obligatori, de títol El catalán que aprenden los alumnos marroquíes. Els criteris d’anàlisi ens havien de permetre descriure les competències lingüístiques i discursives orals de l’alumnat, per poder-les comparar posteriorment.

\section{Competència lingüística}

Per a la competència lingüística, es van considerar els elements següents (adaptació del model de Maruny i Molina (2006)):

Quadre 1. Produccions gramaticals considerades en l'anàlisi

\begin{tabular}{|l|l|}
\hline \multirow{3}{*}{ Lèxic } & Repertori lèxic: substantius, verbs, adverbis, preposicions \\
\cline { 2 - 2 } & $\begin{array}{l}\text { Estratègies lèxiques economitzadores: díctics, hiperònims, } \\
\text { demandes d'ajuda directa, canvis de codi }\end{array}$ \\
\cline { 2 - 2 } & $\begin{array}{l}\text { Estratègies lèxiques explicatives: sinònims, mateix camp } \\
\text { semàntic, perífrasis }\end{array}$ \\
\hline Morfosintaxi & Sintagma nominal: aparició diferents estructures del SN \\
\cline { 2 - 2 } & $\begin{array}{l}\text { Sintagma verbal: diferents temps, modes verbals, formes no } \\
\text { personals, perífrasis verbals }\end{array}$ \\
\cline { 2 - 2 } & Pronoms àtons \\
\hline & Coordinació i subordinació \\
\cline { 2 - 2 } & Morfologia nominal \\
\cline { 2 - 2 } & Morfologia verbal \\
\hline
\end{tabular}


Pel que fa als recursos lèxics ens interessava veure quin ús es feia de substantius, verbs, adverbis i preposicions (considerats com a indicadors de competència (Molina i Maruny 2004). Ens interessava poder comptabilitzar d'alguna manera el repertori i la varietat emprada per l'aprenent sense que haguessin estat introduïts en el torn anterior per la investigadora. És a dir, es tindrien en compte els que aportava el mateix aprenent i que no els que havien estat aportats per la investigadora prèviament (en el torn immediatament anterior). Pel que fa als verbs, a més, es tindria en compte quina relació s’establia amb el que s'expressava (descripcions, deduccions, hipòtesis...). Quant a l'ús d'adverbis i preposicions també era rellevant poder anotar si hi ha havia hagut algun canvi en relació amb el repertori d’aquestes peces i en relació amb el seu ús. En el cas dels adverbis també ens interessava poder descriure’n la tipologia.

A banda de la part més lèxica, era cabdal poder comparar com evolucionaven els recursos gramaticals, entesos com els tipus de construccions oracionals, els tipus de formes verbals emprades i la varietat en els temps verbals. Aquests aspectes ens permetrien correlacionar-los amb les diferents possibilitats d'interpretació que fessin de l'àlbum i amb el grau de complexitat lingüística a l'hora de formular aquestes interpretacions.

Finalment, també es valorarien els tipus de recursos que emprés l'aprenent per fer front a obstacles comunicatius en llengua catalana.

\section{Competència discursiva}

Per a la competència discursiva, es va recórrer a la unitat d'anàlisi que Molina i Maruny (2004) van definir per tal de donar compte de l'aportació de continguts rellevants, sota els criteris de quantitat i qualitat: la unitat d'informació referencial (UIR). En el nostre estudi la UIR es va definir com cada una de les produccions verbals de l'alumne que contenia una informació rellevant en relació amb la imatge que es comentava i en relació amb el conjunt narratiu. El criteri de rellevància vindria determinat pel que la imatge mostra i/o per les inferències realitzades en comentar la imatge i/o per la resposta a la demanda de la investigadora. Com en l'estudi de referència, es van considerar informacions no rellevants les repeticions de les 
produccions verbals de la investigadora, els monosíl·labs de confirmació o de cortesia o els enunciats inacabats.

El càlcul de les UIR produïdes per cada alumne ens permet donar compte de dos indicadors: la densitat discursiva i l'autonomia discursiva. La densitat discursiva, calculada a partir de la relació de nombre de torns necessaris per completar cada UIR, dóna informació sobre la capacitat de produir informació amb més o menys ajuda per part de la interlocutora. D’altra banda, el nombre de UIR encadenades en un sol torn de paraula permet avaluar l'autonomia discursiva de l'aprenent; és a dir, la capacitat d'aportar en un sol torn dues o més informacions rellevants; per tant, la capacitat per expandir el tema sobre el qual es parla i de fer-hi noves aportacions (Nussbaum i Unamuno 2006). A l'estudi de Molina i Maruny (2004), aquest indicador va ser clarament significatiu del progrés dels subjectes en l’adquisició de la llengua.

\section{Comentari dels resultats}

A continuació es detallaran alguns aspectes de les competències que mostren en la segona entrevista els tres participants.

Pel que fa a la competència lingüística, podem dir que en la segona entrevista augmenta lleugerament el repertori lèxic, sobretot pel que fa a la incorporació de nous substantius i verbs. El ventall d’adverbis usat és molt reduït i quasi inalterable en relació amb la primera entrevista. Sobretot són adverbis de funció referencial (lloc: aquí; temps: després).

Un altre aspecte constatable és que augmenta la complexitat sintàctica dels enunciats produïts; una complexitat que abasta un espectre força ampli entre els tres aprenents en relació amb la varietat i la riquesa dels recursos emprats.

En el cas de la Nadia, mentre que en la primera tasca només es localitza un enunciat amb dues oracions, tot i que sense cap element d'enllaç, en el segon cas, la Nadia produeix enunciats més complexos amb un lleuger augment de les oracions coordinades (amb la conjunció i) i de les causals. L’augment de l’ús de les oracions causals introduïdes per la conjunció perquè ens permet apuntar que en la segona entrevista es troba en més disposició d’argumentar el que expressa. Com hem dit, mentre que en la primera entrevista el 60\% dels enunciats introduïts per la conjunció 
causal són inacabats i incomplets (acaba abandonant la comunicació); en la segona només ho fa en el 21\% dels casos. En aquest segon cas, per tant, no només descriu el que veu en les imatges, sinó que en algunes ocasions, quan se li demana el perquè d'algunes qüestions que ha expressat, es llança a donar l'explicació del motiu, a justificar el que ha dit. Així, el discurs de la Nadia obre la porta a intents més o menys agosarats de donar la seva opinió a partir de l'experiència personal, i per tant, de mostrar-se més arriscada en l'expressió.

En aquest sentit, l’Alberto també es mostra més expansiu i es pot evidenciar una major implicació en la narració de la història de l’àlbum. Aquest fet té una correlació directa amb el tipus de discurs i d'enunciats que produeix. Augmenta de manera notable l’ús de perífrasis verbals de base significativa (que tenen una significació específica); la qual cosa implica que és més capaç de matisar allò que vol expressar. Així, mentre que la perífrasi de sentit duratiu és present en les dues entrevistes (estar + gerundi), en la segona la precisió de les accions és més acurada. També hi localitzem perífrasis de continuïtat i de possibilitat. La presència d'aquestes matisacions semàntiques té relació amb el que vol expressar, que esdevé més precís i amb més implicació interpretativa en la segona tasca.

El cas de Thiane presenta diferències respecte als altres dos participants. La primera entrevista és molt més extensa i complexa que no pas la segona. Per exemple, mentre que a la primera hi localitzem oracions subordinades temporals i causals i una de relatiu, en el segon cas bàsicament trobem oracions simples o bé coordinades a través de la conjunció $i$, i algunes causals (tot i que en menor nombre). De totes maneres, el discurs de Thiane en la segona entrevista perd el caràcter hipotètic que ha impregnat les seves interpretacions en la primera; al contrari, es torna més segur a l’hora de construir sentit al que succeeix a l’àlbum. En la primera entrevista localitzem fins a set enunciats encapçalats per la perífrasi pot ser que:

Fragment 1. Thiane, 1a entrevista

\begin{tabular}{|l|l|l|}
\hline 41. & THI: & pot ser que el nen ha jugat i després ha donat\} |
\end{tabular}

Fragment 2. Thiane, 1a entrevista

\begin{tabular}{|l|l|l|}
\hline 183. & THI: & aquí pot ser que és_és Àfrica $\mid$ \\
\hline
\end{tabular}


En la segona, només se’n localitza un. Les seves interpretacions, doncs, no es revesteixen del caràcter de possibilitat i més aviat són expressades amb seguretat i afirmació.

D’altra banda, la manera com fan front als obstacles comunicatius també difereix força d'un aprenent a un altre. El que podem destacar és que les imatges de l’àlbum són una gran ajuda per assegurar la seva comunicació. En el cas de la Nadia, tant en la primera com en la segona entrevista, la referència de la imatge li permet suplantar obstacles comunicatius. Així, la utilització del pronom esto només es pot entendre si es té al davant la imatge a què es refereix. Per tant, l'àlbum proporciona un marc en què el llenguatge queda del tot contextualitzat per a ella i per a la seva interlocutora i per tant li és molt més senzill expressar-se fent un ús més implícit, no tan explícit, del llenguatge.

Les demandes d’ajuda a la interlocutora bàsicament són fetes a partir de procediments com els allargaments sil·làbics o l'abandó del discurs. En molt poques ocasions es recorre a la demanda explícita d'ajuda per solucionar un problema comunicatiu:

Fragment 3. Thiane, 2a entrevista

\begin{tabular}{|l|l|l|}
\hline 104. & THI: & i aquest peix ho va_no sé com es diul| \\
\hline 105. & INV: & pescat/| \\
\hline 106. & THI: & pescat sí $\mid$ i ho van portar cap a Àfrica $\mid$ \\
\hline
\end{tabular}

Pel que fa a la competència discursiva, farem referència a la producció d'unitats d'informació referencial (UIR) que els aprenents produeixen en cada cas per tal de valorar la densitat i l'autonomia discursiva en una i altra entrevista. Recordem que la densitat ens permet donar compte del grau d'ajuda que es necessita de la interlocutora per dur a terme els enunciats i, per tant, de la fluïdesa dels discurs; mentre que l'autonomia discursiva ens dóna informació sobre la capacitat per expandir el tema sobre el qual es parla i de fer-hi noves aportacions, mesurada a partir de les informacions rellevants aportades en un sol torn de paraula. Cal recordar que aquest 
últim indicador va ser clarament significatiu del progrés dels subjectes en l'adquisició de la llengua a l’estudi de Molina i Maruny (2004).

En els tres casos analitzats podem afirmar que hi ha un augment de la competència discursiva. La densitat discursiva i l'autonomia augmenta tot i que amb proporcions desiguals segons el cas.

En la primera entrevista, dels 166 torns en què intervé la Nadia, podem localitzar 59 UIR, és a dir una densitat discursiva del 35.5\%. Es necessiten tres torns de paraula per completar una sola informació, cosa que ens porta a apuntar la constant aportació d'ajuda de tot tipus que fa la interlocutora. D'altra banda, pel que fa a l'autonomia discursiva, en aquest primer cas, és molt limitada: en la primera entrevista només es localitza un sol torn de paraula amb dues UIR.

En la segona entrevista, podem aportar dades que, si bé limitades, ens permeten indicar una lleugera millora en la competència comunicativa d'aquesta aprenent. En aquest segon cas, dels 182 torns en què intervé, produeix 70 UIR, que equival a una densitat del 38.46\%. Com hem dit, és cert que en relació amb la primera entrevista augmenta poc la densitat discursiva, però augmenta i aquesta part és la que ens interessa recalcar. També augmenta lleugerament l'autonomia discursiva; localitzem dos torns de paraula, un amb dues UIR i un altre amb 4.

El cas de l’Alberto també és significatiu en relació amb la millora de la competència discursiva. Dels 115 torns de paraula en què participa, en la primera entrevista, es localitzen 90 UIR; és a dir, en la primera entrevista hi ha una densitat discursiva del $75.65 \%$. En quasi cada torn aporta una informació rellevant per a la continuïtat de l'entrevista. Pel que fa a l'autonomia discursiva, localitzem 13 torns de paraula amb dues UIR, dos dels quals amb 3. En la segona entrevista, la densitat discursiva és quasi del 100\%, del 98.59\%. Participa en 142 torns i localitzem 140 UIR. Pràcticament a cada torn de paraula, doncs, hi localitzem una UIR. Per tant, aporta molta informació i hi ha molt poca presència de la interlocutora en relació amb les ajudes davant d'obstacles de comunicació. Al contrari, s'estableix un diàleg fluid entorn de l'àlbum al qual l'Alberto respon amb seguretat i de forma expansiva. Així, l'autonomia discursiva en aquest segon cas augmenta considerablement: localitzem 27 torns de paraula amb més d'una UIR, 11 dels quals presenten més de 3 o 4 UIR. 
Si bé la competència gramatical de Thiane oferia resultats poc reveladors, en relació amb la competència discursiva sí que podem aportar dades significatives. Pel que fa a la densitat discursiva, en la primera entrevista Thiane participa en 128 torns de paraula i es localitzen 92 UIR (un 71,87\%), és a dir que quasi a cada torn i hi ha una UIR completa. En el segon cas, participa en 83 torns (ja hem dit que la segona entrevista és més curta), però hi localitzem 59 UIR (71\%). Per tant, malgrat que no és tan expansiu en la segona activitat, no varia quasi la densitat discursiva. Necessita molt poca ajuda per part de la investigadora per portar a terme la tasca. Pel que fa a l'autonomia discursiva, en la primera entrevista es localitzen 7 torns amb més de 2 UIR (per tant, en el 5,46\% dels torns); mentre que en la segona, l'autonomia és més elevada i dels 83 torns, se'n localitzen igualment 7 amb més de 2 UIR, però que representen el 8,43\% dels torns. Una diferència de 3 punts. Per tant, en la segona entrevista, malgrat ser més curta i anar més per feina, Thiane expandeix més les seves informacions, hi aporta més informacions noves i rellevants.

\section{Compartir la lectura de l'àlbum amb els altres}

Els resultats obtinguts ens permeten dir que en la segona entrevista han expressat més coses en relació amb la lectura de l'àlbum i han recorregut a un repertori gramatical lleugerament més ampli. Però què ha permès bastir les produccions amb més informació? Indubtablement, la sessió de lectura compartida hi ha tingut una influència rellevant.

La sessió de lectura amb tot el grup va oferir l'espai perquè es despleguessin interpretacions i mirades sobre l'àlbum que o bé havien restat ocultes o havien passat desapercebudes per a alguns dels nois i noies participants. Algunes d'aquestes interpretacions que es van compartir, es van localitzar posteriorment, reelaborades i expressades de manera diferent en el discurs d'alguns dels nois i noies de la segona entrevista. La posada en comú de les diverses interpretacions i respostes lectores a l’obra va crear el marc perquè les de cadascú anessin creixent a través de la interacció amb els altres lectors. La lectura grupal va permetre, doncs, revisar i reactualitzar la primera lectura. 
Recordem, per exemple, el cas de Thiane. Si la entrevista inicial es caracteritza per transmetre un caràcter més aviat hipotètic o de possibilitat, segurament el fet d'haver aprofundit més en la lectura de l'àlbum en la sessió de grup fa que les seves interpretacions recobrin seguretat i puguin ser expressades sense haver de matisar-les (pot ser que...) en la segona entrevista.

El cas de l'Alberto també és destacable pel nivell d’implicació personal que mostra en la segona entrevista. Hi ha una mirada més subjectiva del que passa a la història i és més fàcil localitzar-hi enunciats en què expressa la seva opinió personal respecte al que mostra cada seqüència il-lustrativa o quan es posa en la pell dels personatges i expressa el que creu que deuen pensar, a partir de les inferències que pot establir entre allò que mostra la imatge i el coneixement del funcionament del món real. Seria el cas de la seqüència que presentem, quan l'Alberto comenta la imatge del turista que compra al nen africà per un dòlar el cotxe fet de llauna amb el soldadet i la barbie.

Fragment 4. Alberto, 2a entrevista

\begin{tabular}{|l|l|l|}
\hline 202. & ALB: & pensando però este cotxe en el seu país vale molt més no/| \\
\hline 203. & INV: & sí sí sí $\mid$ \\
\hline 204. & ALB & i és una estafa $\bigvee$ \\
\hline 205. & INV: & és una estafa sí sí eh/| tal com has dit tu $\backslash$ i el nen per què accepta?| \\
\hline 206. & ALB: & perquè para el no sap molt eso dels diners $\backslash$ \\
\hline
\end{tabular}

Aquest fragment és revelador de la influència de la lectura compartida en les interpretacions posteriors. Una anàlisi acurada de la sessió de grup ens va permetre identificar seqüències interpretatives que sortien en la segona entrevista, però que en canvi no s'hi havia fet esment anteriorment. La referència a la situació d’injustícia i d'estafa que expressa l'Alberto en aquest fragment, en la sessió de grup va ser elaborada per Thiane.

La implicació i l'entusiasme van ser dos dels trets que van caracteritzar la participació dels nois i noies, a pesar de les diferències de nivell, a pesar de les diferències de les competències lingüístiques. Tots volien expressar allò que veien, justificar escenes, expressar la seva opinió cap a seqüències de l’àlbum; rebatre o confirmar interpretacions dels altres. Hi va haver, doncs, ganes de comunicar-se en detriment de la por de no fer-ho correctament en català. La percepció que el que interessava era l’expressió de significats i no només l’avaluació de l’ús lingüístic fou 
una de les condicions que va afavorir la participació de l'alumnat comunicativament parlant.

El que han demostrat els nois i noies en la sessió de grup i en la segona entrevista, com ara la capacitat de poder expressar-se més enllà de la mera descripció de la imatge, o la capacitat de poder aportar al seu discurs funcions del llenguatge tan diverses com opinar, exclamar, justificar, demostra que quan el material amb què es treballa arriba a l'aprenent, encara que no es domini la llengua, obre la porta a la interpretació i a l'expressió. Com diu Coulthard (2004), arran de la seva experiència amb infants nouvinguts, assumir riscos i cometre errors forma part del procés d'aprenentatge de la llengua i d'aprenentatge de la lectura. El que fa que un alumne acabat d'arribar sigui capaç d'assumir aquesta responsabilitat davant d'un text visual i respongui, amb els seus recursos, és que no hi ha pressió per parlar; és que percep que la importància en aquest tipus de tasca rau en el fet de construir i comunicar significat i no en respondre correctament:

¿Por qué decidió que valía la pena el esfuerzo? La elección del texto responde en parte a esta pregunta. Para Sam, El túnel es un texto emocionalmente fuerte, al que responde desde el interior de su experiencia. Además, de forma importante, el enfoque en encontrar el significado de un texto visual le permite responder. Otra posible explicación es que el contexto de la entrevista es auténtico. En verdad me interesa saber lo que piensa Sam al entrar en un diálogo sobre su comprensión, con la seguridad de que no estoy avaluando su capacidad de interpretar palabras dificiles ni el grado de desarrollo de su escaso vocabulario en inglés. (Coulthard 2004:243)

\section{Conclusions}

Amb aquest article hem volgut posar de relleu les potencialitats que té la lectura compartida d'un àlbum en una aula d'acollida. D'una banda, l'absència de text ofereix d'entrada la possibilitat d'implicar-se en la interpretació de les il-lustracions de manera més directa, sense les limitacions que la paraula escrita pot suposar per a qui encara no domina els mecanismes de la lectura en la llengua objecte d'aprenentatge. De l'altra, compartir la lectura de l'àlbum i parlar-ne crea un context afavoridor per a la pràctica de competències de producció oral de l'alumnat nouvingut.

L’àlbum, si connecta amb els seus interessos, si els és estimulant i significatiu, els obre la porta a l'expressió. I cal fer-los entendre que el que ens interessa és el que 
expressen i el que construeixen de sentit i no només l’avaluació dels recursos lingüístics que empren. Aquesta recerca ens ha demostrat que amb un àlbum il·lustrat també es poden garantir oportunitats per usar i aprendre la llengua en ús.

\section{Referències bibliogràfiques}

Arizpe, E. i Styles, M. (2008) The voices behind the pictures. Children responding to postmodern picturebooks. Dins Sipe, L. \& Pantaleo, S.: Postmodern picturebooks. Play, Parody and Self-referentiality (pàg. 213-217). Nova York: Routledge.

Coulthard, K. (2004) Las palabras para expresarlo. Alumnos bilingües responden a textos visuales. Dins Arizpe, E., Styles, M.: Lectura de imágenes. Los niños interpretan textos visuales (pàg. 239-277). Mèxic: Fondo de Cultura Económica, 2004.

Datta, M. (2000) Bilinguality, imagination and literature. Dins M. Datta (Ed.) Bilinguality and Literacy, Principles and Practice, pp. 1-28. London: Continuum. http://www.multiverse.ac.uk/attachments/05168b62-41ab-40808950-6c728b31b200.pdf[data de consulta: 16 abril de 2010]

Margallo, A. (2008, abril): ¿Qué tipo de corpus facilita la integración y el aprendizaje lingüístico y literario de los alumnos recién llegados? Comunicació presentada a les 9èmes Rancontres des Chercheurs en Didactique de la Littérature. Bordeus, 3-5 d'abril de 2008. http://www.pangea.org/gretel-

uab/images/stories/burdeosgretelanamaria.pdf [data de consulta 16 d'abril de 2010]

Maruny, L. i Molina, M. (2006) L'adquisició del català en alumnes d'origen marroquí a l'ensenyament obligatori. Dins Vila, F.X., Boix-Fuster, E., Alturo, N. (ed.): Integrar des de la fragilitat? Societats plurilingües davant el repte de les immigracions multilingües: Suïssa, Brussel·les, Luxemburg, Quebec, Catalunya (pàg. 71-81). Barcelona: Institut d'Estudis Catalans.

Molina, M. i Maruny, L. (2004) El catalán que aprenden los alumnos marroquíes. Escuela e inmigración, n. especial d'Estudios de Sociolingüística, 5(2), pàg. 323-348. http://www.sociolinguistica.uvigo.es/articulosXvolumen.asp?id=27 [data de consulta: 16 abril de 2010]

Müller, J. (2005) El soldadito de plomo. Salamanca: Lóguez.

Murgades, J. (coord.) (2006) Conclusions de la comissió de Didàctica de la literatura. L'ensenyament de la literatura a l'ensenyament no universitari. Dins Consell assessor de la llengua a l'escola: Conclusions. Barcelona: Generalitat de Catalunya.

Nussbaum, L. i Unamuno, V. (2004) Competències orals multilingües d'alumnat estranger a Catalunya. A: III Jornades Institut Europeu de programes d'immersió: Cap al plurilingüisme des de la immersió. Barcelona.

Nussbaum, L. i Unamuno, V (eds.) (2006) Usos i competències multilingües entre escolars d'origen immigrant. Barcelona: UAB

Nussbaum, L. (2007) Prototipos de actividades en el aula. Document inèdit. Barcelona: Universitat Autònoma de Barcelona. 
Silva-Díaz, M.C. i Manresa, M. (2005) Dialogar per aprendre literatura. Articles de Didàctica de la llengua i la literatura, 37: 45-55.

Silva-Díaz, C. (2006): “La función de la imagen en el álbum”a Peonza. Revista de Literatura infantil y juvenil, núm. 75-76, P. 23-33. http://www.cervantesvirtual.com/servlet/SirveObras/0581746341160381742785 7/ima0022.htm [data de consulta: 16 abril de 2010]

Referència de la autora:

Montserrat Pérez i Ventayol és professora associada del Departament de Didàctica de la Llengua i la Literatura de la Facultat de Ciències de l'Educació de la UAB, i tècnica de normalització lingüística del Consorci per a la Normalització Lingüística. És membre del grup GRETEL (Grup de Recerca en Literatura Infantil i Juvenil i Educació Literària) de la UAB, dirigit per la doctora Teresa Colomer. Les seves línies de recerca són didàctica de la literatura i aprenentatge lingüístic.

Email: montserrat.perez.ventayol@uab.cat

1 GRETEL (Grup de Recerca de literatura infantil i juvenil i educació literària de la Universitat Autònoma de Barcelona). L'equip GRETEL està dirigit per la doctora Teresa Colomer.

2 Treball de Recerca de Màster de Recerca en Didàctica de la Llengua i la Literatura, del Departament de Didàctica de la Llengua i la Literatura i de les CCSS de la UAB. El treball s’emmarca en el projecte de recerca finançat I+D: EDU2008-02131/EDUC La interpretación literaria de álbumes ilustrados en el proceso de acogida de alumnos immigrantes del grup GRETEL, dirigit per Teresa Colomer.

${ }^{3}$ Que el títol fos en castellà no va ser un obstacle per a la investigació, ja que era un àlbum sense text. 